\title{
Development of ready to drink calcium fortified shrimp soup in retortable pouches
}

\author{
K. SHASHIDHAR, K. B. BIJI, C. N. RAVISHANKAR, T. K. SRINIVASA GOPAL \\ AND JOSE JOSEPH \\ ICAR-Central Institute of Fisheries Technology, Matsyapuri P. O, Kochi - 682 029, Kerala, India \\ e-mail:cnrs2000@gmail.com
}

\begin{abstract}
The aim of the study was to develop ready to serve calcium fortified shrimp soup in retortable pouches. Shrimp soup was prepared from Indian white shrimp (Fenneropenaeus indicus) and thermal processed at 121,115 and $110^{\circ} \mathrm{C}$ to an $\mathrm{F}_{0}$ value of 6. The calcium fortified soup was then compared with control samples. The effect of different process temperatures on quality was analysed. The samples processed at $110^{\circ} \mathrm{C}$ showed significantly higher $(\mathrm{p} \leq 0.05)$ cook value and $121.1^{\circ} \mathrm{C}$ showed the least. All the pouches were found to be commercially sterile. The viscosity of soup was significantly higher $(\mathrm{p} \leq 0.05)$ in control packs compared to fortified soups. Significantly higher $(p \leq 0.05) b^{*}$ value was observed in fortified soup compared to control. Thermally processed calcium fortified shrimp soup was in acceptable condition during the storage period of 90 days at ambient temperature without any significant change in calcium content. Sensorily, the product processed at $121^{\circ} \mathrm{C}$ rated better compared to 115 and $110^{\circ} \mathrm{C}$.
\end{abstract}

Keywords: Fenneropenaeus indicus, Ready to drink, Retortable pouches, Shrimp soup, Thermal processing

\section{Introduction}

Convenience foods are designed to save consumers' time, reduce wastage from spoilage and also to reduce financial costs. These products include ready to cook, ready to fry and ready to serve forms. Soup is a value added savory liquid food, made by combining ingredients such as meat or vegetables in stock or hot water, until the flavour is extracted, forming a broth (Holt and Miller, 1995). Shelf life of soup is limited to one day at room temperature without the addition of preservatives. At refrigerated temperatures $\left(2\right.$ to $\left.3^{\circ} \mathrm{C}\right)$ shelf life may extend for few more days. Thermal processing is one of the most effective means of preserving food (Karel et al., 1975). Ready to drink thermal processed soups can attract consumer preference owing to the convenience of usage. Several researchers (Goldfarb, 1970; Hu et al., 1995; Ravishankar et al., 2002; Bindu et al., 2004) have proven the technical and commercial feasibilities of using retortable pouches for thermal processing.

Food fortification is the addition of one or more essential nutrients, whether or not normally contained in the food, for the purpose of preventing or correcting a demonstrated deficiency of one or more nutrients in the population or specific population groups (FAO/WHO, 1994). In the food industry, fortification with calcium is a common practice in order to improve the functional and nutritional properties of food (Kaushik et al., 2014; 2015). Calcium is an important mineral required by the body for a variety of physiological functions and for the maintenance of bone tissues throughout life (Broadus, 1996). Hence there is a great potential for calcium fortified foods in order to meet the calcium requirements of our body. Keeping these in view, the present work was undertaken to standardise the total process time for the production of calcium fortified shrimp soup in a ready to drink form.

\section{Materials and methods}

Flexible pouches of 3 ply laminate consisting of outer polyester of $12.5 \mu$, middle aluminium foil of $12.5 \mu$ and inner cast polypropylene of $85 \mu$ thickness and size 16 x $20 \mathrm{~cm}$ manufactured by M. H. Packaging, Ahmedabad, India was used for the study.

Fish calcium powder was made by sterilising the bones of threadfin breams (Nemipterus japonicus) at $121^{\circ} \mathrm{C}$ for $30 \mathrm{~min}$ in a laboratory scale autoclave. The softened fish bones were then dried in a Solar Tunnel drier at $44 \pm 2^{\circ} \mathrm{C}$ for $10-12 \mathrm{~h}$. These bones were then made into fine powder and used for the study.

Indian white shrimp (Fenneropenaeus indicus) was used for making soup in the present study. Shrimps were collected from Fort Kochi fish landing centre at Kochi, Kerala, iced immediately at shrimp : ice ratio of 1:1 and brought to the laboratory in insulated boxes. After reaching the laboratory, samples were de-iced, peeled, deveined, then washed in chilled potable water and drained for $5 \mathrm{~min}$. 
The ingredients used for preparing shrimp soup are given in Table 1. Onion and ginger-garlic paste was fried in sunflower oil till it turned golden brown in colour. Water and salt were added to this and boiled. Corn flour and $350 \mathrm{ppm}$ of bone powder were mixed with potable water and added to the boiling solution and stirred to attain the required consistency. Control soup was prepared without adding bone powder. Hot blanched (in $4 \%$ brine at $100^{\circ} \mathrm{C}$ for $1-2 \mathrm{~min}$ ) shrimps (100 g) was added to the pouches along with soup medium. Air inside the pouches were exhausted by steam injection. The pouches were heat sealed and processed in a stationary over pressure retort (John Fraser and Sons Ltd., UK) at three different temperatures viz., 121,115 and $110^{\circ} \mathrm{C}$ at $\mathrm{F}_{0} 6$. The process data was taken by inserting thermocouple needles into the center of the pouch. Thermocouple outputs were measured using an Eval precision thermometer and process integrator (Ellab, Denmark). The recorded data were analysed using valsuite software. The heat penetration data were plotted on a semi logarithm paper with temperature deficit (RT-CT) in logarithmic scale on Y axis against time in linear scale on $\mathrm{X}$ axis. Lag factor for heating $\left(\mathrm{J}_{\mathrm{h}}\right)$, lag factor for cooling $\left(\mathrm{J}_{\mathrm{c}}\right)$, slope of the heating curve $\left(\mathrm{f}_{\mathrm{h}}\right)$ and time in minutes for sterilisation at retort temperature (U) were determined. The process time (B) was calculated by mathematical method (Stumbo, 1973). Actual process time $(\mathrm{T})$ was determined by adding process time (B) and the effective heating period during come up time i.e., $58 \%$ of the come up time.

Thermal processed pouches were tested for commercial sterility (IS 2168, 1971). The proximate composition of the samples was determined by AOAC (2000) method. Indole content was analysed spectrophotometrically as per the method of Cheuk and Finne (1981). TVB-N and TMA-N contents were analysed following Conway (1950). $\mathrm{pH}$ was determined according to IS: 2168-1971. Thiobarbituric acid values were determined spectrophotometrically as per the method of Tarladgis et al. (1960). Calcium in the sample was analysed in Atomic Absorption Spectrophotometer

Table 1. Ingredients used for the preparation of shrimp soup

\begin{tabular}{ll}
\hline Ingredients & Quantity added \\
\hline Shrimp & $100 \mathrm{~g}$ \\
Corn flour & $40 \mathrm{~g}$ \\
Pepper & $10 \mathrm{~g}$ \\
Ginger & $10 \mathrm{~g}$ \\
Butter & $250 \mathrm{~g}$ \\
Onion & $100 \mathrm{~g}$ \\
Water & $1000 \mathrm{ml}$ \\
Salt & To taste \\
Bone powder* & $350 \mathrm{ppm}$ \\
\hline
\end{tabular}

*Added only for fortified samples
(Barian Spectra-220, AA). Viscosity of shrimp soup was measured using a Brookfield DV II+ Viscometer (Brook field Engineering Laboratory Inc., Stoughton, M. A). The colour of both control and fortified soups were measured instrumentally with Hunter Mini Scan XE Plus.

Sensory analysis of thermal processed shrimp soup was carried out by ten trained panelists using a 9 point hedonic scale as prescribed by Meilgaard et al. (1999). Sensory evaluation was based on characterisation and differentiation of the various sensory characters such as appearance, colour, odour, flavour, taste and consistency.

All analyses were carried out in triplicate. Data were analysed by using one way ANOVA and the least significant difference (LSD) was calculated at the probability level $\mathrm{p}<0.05$.

\section{Results and discussion}

Soup was processed to different temperatures viz., 121,115 and $110^{\circ} \mathrm{C}$ with $\mathrm{F}_{0} 6$. The processed pouches of all three batches were found to be commercially sterile, indicating that the thermal processing given was sufficient for commercial sterility. Heat penetration data of shrimp soup processed at three different temperatures are given in Table 2. The come up time (CUT) was in the range of 5 to $7 \mathrm{~min}$. According to NCA (1968), the CUT should be as short as possible. $\mathrm{F}_{\mathrm{h}}$ was 6.4 and 6.5 for samples processed at $121.1^{\circ} \mathrm{C}$ for control and calcium fortified samples (Table 2). Whereas it was 9.5 and 10.5 for samples processed at $110^{\circ} \mathrm{C}$ for control and iron fortified samples. The sample processed at $121.1^{\circ} \mathrm{C}$ took the least total process time (B) and the sample processed at $110^{\circ} \mathrm{C}$ took the maximum. After thermal processing, samples were cooled to around $35^{\circ} \mathrm{C}$ to prevent overcooking of the product and survival of thermophiles. The cook value of the samples showed that shrimp soup processed at $121.1^{\circ} \mathrm{C}$ had the least and the soup processed at $110^{\circ} \mathrm{C}$ showed the highest cook value. The cook value which is a measure of heat treatment with respect to nutrient degradation and textural changes that occur during processing, was determined by measuring the extent of cooking and nutritional loss during processing (Ranganna, 2000). In the present study, cook value increased with total process time.

The results of biochemical analyses of fresh shrimp used for the study are given in Table 3 . The indole value for raw shrimp was $0.93 \mu 100 \mathrm{~g}^{-1}$ which indicates that the shrimps used for the study were in fresh condition. Indole was not observed in soup after thermal processing. Other quality parameters like TVB-N, TMA and TBA were $11.25 \mathrm{mg} \mathrm{N} 100 \mathrm{~g}^{-1}, 1.48 \mathrm{mg} \mathrm{N} 100 \mathrm{~g}^{-1}$ and 0.49 malonaldehyde $\mathrm{kg}^{-1}$ respectively, which also shows the freshness of shrimp used for the study. Peroxide value 
Table 2. Heat penetration characteristics of shrimp soup prepared at three different temperatures

\begin{tabular}{|c|c|c|c|c|c|c|}
\hline \multirow{3}{*}{ Parameters* } & \multicolumn{6}{|c|}{ Processing temperature } \\
\hline & \multicolumn{2}{|c|}{$121^{\circ} \mathrm{C}$} & \multicolumn{2}{|c|}{$115^{\circ} \mathrm{C}$} & \multicolumn{2}{|c|}{$110^{\circ} \mathrm{C}$} \\
\hline & $\mathrm{CON}$ & $\mathrm{CF}$ & $\mathrm{CON}$ & $\mathrm{CF}$ & $\mathrm{CON}$ & $\mathrm{CF}$ \\
\hline Fo value & 6.21 & 5.99 & 6.24 & 6.06 & 6.13 & 6.15 \\
\hline$J_{h}$ & 0.51 & 0.72 & 0.78 & 0.97 & 0.45 & 0.38 \\
\hline$J_{c}^{h}$ & 1.07 & 1.07 & 1.13 & 1.02 & 1.01 & 1.08 \\
\hline$f_{h}^{c}$ & 6.4 & 6.5 & 7.1 & 8.4 & 9.5 & 10.5 \\
\hline $\mathrm{U}$ & 6.21 & 5.91 & 25.42 & 24.69 & 78.97 & 78.97 \\
\hline$f_{h} / u$ & 1.03 & 1.1 & 0.28 & 0.34 & 0.12 & 0.12 \\
\hline$g$ & 0.58 & 0.68 & 0 & 0.01 & 0 & 0 \\
\hline $\mathrm{B}$ & 12.1 & 12.88 & 32.06 & 33.6 & 59.88 & 62.78 \\
\hline CUT & 6 & 7 & 6 & 5 & 7 & 7 \\
\hline TPT & 15.58 & 16.94 & 35.54 & 36.5 & 63.94 & 66.84 \\
\hline Cook value & 40.31 & 41.79 & 80.97 & 82.18 & 145.23 & 142.13 \\
\hline
\end{tabular}

CON: control soup, CF: calcium fortified soup, Jh: lag factor of heating, Jc: lag factor of cooling, fh: slope of heating curve, U: time in minutes for sterilisation at retort temperature, g: final temperature deficit, B: Ball's process time, CUT: Retort come up time, TPT: total process time

Table 3. Biochemical quality of fresh shrimp

\begin{tabular}{|c|c|}
\hline Parameter* & Value \\
\hline $\mathrm{pH}$ & $6.73 \pm 0.13$ \\
\hline Indole $\left(\mathrm{mg} 100 \mathrm{~g}^{-1}\right)$ & $0.93 \pm 0.03$ \\
\hline TBA value (mg melonaldehyde $\mathrm{kg}^{-1}$ ) & $0.49 \pm 0.16$ \\
\hline TVB-N (mg N $\left.100 \mathrm{~g}^{-1}\right)$ & $11.25 \pm 1.12$ \\
\hline TMA (mg N $\left.100 \mathrm{~g}^{-1}\right)$ & $1.48 \pm 0.17$ \\
\hline Peroxide value (Milli equivalent $\mathrm{kg}$ fat $^{-1}$ ) & Nil \\
\hline FFA $(\%$ oleic acid $)$ & $1.08 \pm 0.18$ \\
\hline
\end{tabular}

"Each value is represented by mean \pm SD of at least 3 determinates

TBA: Thiobarbutiric acid, TVB-N: Total volatile base nitrogen, TMA: Trimethyl amine, FFA: Free fatty acids

was not observed in the shrimp samples. $\mathrm{pH}$ of fresh shrimp was 6.73 which was similar to the result reported for Indian white shrimp (Mohan, 2004). The formation of secondary oxidation products was measured by means of thiobarbituric acid (TBA). TBA of fresh shrimp (0.49 mg malonaldehyde $\mathrm{kg}^{-1}$ ) was well below the lipid spoilage indices, established at 3 or less mg malonaldehyde $\mathrm{kg}^{-1}$ of muscle (Huss, 1995).

The proximate composition of $F$. indicus (Fig. 1) showed that the sample contained $80.82 \%$ moisture, $16.48 \%$ protein and $2.4 \%$ crude fat. It was in agreement with the earlier findings by Mohan et al. (2006) in terms of protein and moisture. The proximate composition of raw soup showed that it contained $94.82 \%$ moisture and $3.67 \%$ protein (Fig. 1). Fat and ash content of the soup was 1 and $1.1 \%$ respectively. No significant difference in moisture and protein content was observed in shrimp soup after thermal processing and during the storage period (Table 4). The weight loss in muscle foods after thermal processing is due to the cook loss of water, lipids and solids, mainly collagen, gelatin and coagulated sarcoplasmic proteins (Kong et al., 2007). Thermal

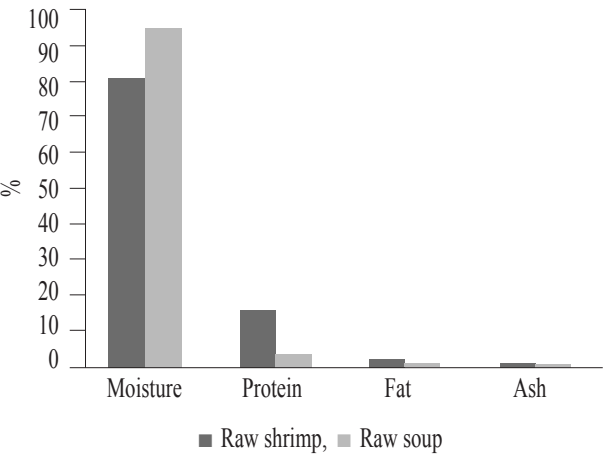

Fig. 1. Proximate composition of raw shrimp and raw soup. Each value is the average of at least 3 replications

denaturation of muscle proteins leads to moisture loss (Bell et al., 2001) due to the decrease of water holding capacity of myofibrillar proteins (Castrillon et al., 1996). Since the present study analysed the total proximate composition of shrimp soup, the protein denaturation and subsequent water loss from shrimp muscle was not found to influence the total proximate composition of the soup. $\mathrm{pH}$ of the product was slightly acidic and did not vary with thermal processing and storage (Table 5). A Similar result was also reported by Mallick (2003) in rohu curry and Prasanna (2004) in sardine in oil and brine. There was a slight decrease in TBA value in thermally processed soup compared to raw soup (Table 5). Similar results were also reported by Chia et al. (1983) and Heidelbaugh and Karel (1970). This decrease might be attributed to the fact that the secondary oxidation products released from the muscle into the aqueous medium might have reacted with other reactive compounds like amino groups, resulting in its reduction (Pokorny, 1981; Aubourg et al., 1995). There was no significant change in TBA during storage period. The peroxide value estimated in raw soup and processed 
Table 4. Biochemical analysis of processed shrimp soup during storage

\begin{tabular}{|c|c|c|c|c|c|c|c|}
\hline & Months & $121^{\circ} \mathrm{CON}$ & $115^{\circ} \mathrm{CON}$ & $110^{\circ} \mathrm{CON}$ & $121^{\circ} \mathrm{CF}$ & $115^{\circ} \mathrm{CF}$ & $110^{\circ} \mathrm{CF}$ \\
\hline \multirow[t]{4}{*}{ Moisture* } & 0 & $94.57 \pm 0.02^{\mathrm{a}}$ & $94.72 \pm 0.26^{\mathrm{a}}$ & $94.76 \pm 0.13^{\mathrm{a}}$ & $94.49 \pm 0.07^{\mathrm{c}}$ & $94.19 \pm 0.05^{\mathrm{b}}$ & $95.13 \pm 0.03^{\mathrm{ab}}$ \\
\hline & 1 & $94.74 \pm 0.09^{a}$ & $95.07 \pm 0.14^{\mathrm{a}}$ & $94.79 \pm 0.50^{\mathrm{a}}$ & $94.79 \pm 0.08^{b}$ & $94.88 \pm 0.05^{\mathrm{a}}$ & $95.48 \pm 0.05^{\mathrm{a}}$ \\
\hline & 2 & $94.62 \pm 0.22^{\mathrm{a}}$ & $94.95 \pm 0.10^{\mathrm{a}}$ & $95.04 \pm 0.03^{\mathrm{a}}$ & $95.25 \pm 0.17^{\mathrm{a}}$ & $93.75 \pm 0.08^{c}$ & $95.04 \pm 0.08^{\mathrm{ab}}$ \\
\hline & 3 & $93.21 \pm 0.37^{\mathrm{b}}$ & $93.22 \pm 0.20^{\mathrm{b}}$ & $93.73 \pm 0.18^{\mathrm{b}}$ & $93.63 \pm 0.07^{\mathrm{d}}$ & $93.30 \pm 0.26^{\mathrm{d}}$ & $94.50 \pm 0.05^{\mathrm{b}}$ \\
\hline \multirow[t]{4}{*}{$\mathrm{CP}^{*}$} & 0 & $4.37 \pm 0.24^{\mathrm{a}}$ & $4.31 \pm 0.24^{\mathrm{b}}$ & $4.52 \pm 0.16^{\mathrm{a}}$ & $3.60 \pm 0.00^{\mathrm{a}}$ & $3.51 \pm 0.26^{\mathrm{a}}$ & $3.42 \pm 0.27^{\mathrm{ab}}$ \\
\hline & 1 & $3.92 \pm 0.14^{\mathrm{a}}$ & $4.41 \pm 0.13^{\mathrm{b}}$ & $4.64 \pm 0.00^{\mathrm{a}}$ & $3.59 \pm 0.02^{\mathrm{ab}}$ & $3.60 \pm 0.09^{\mathrm{a}}$ & $3.42 \pm 0.03^{\mathrm{a}}$ \\
\hline & 2 & $3.64 \pm 0.24^{\mathrm{a}}$ & $3.79 \pm 0.25^{\mathrm{ab}}$ & $3.89 \pm 0.30^{\mathrm{a}}$ & $3.55 \pm 0.00^{\mathrm{b}}$ & $3.69 \pm 0.23^{\mathrm{ab}}$ & $3.57 \pm 0.05^{\mathrm{ab}}$ \\
\hline & 3 & $3.30 \pm 0.27^{b}$ & $3.36 \pm 0.15^{\mathrm{a}}$ & $3.79 \pm 0.24^{b}$ & $3.71 \pm 0.17^{\mathrm{b}}$ & $3.98 \pm 0.11^{\mathrm{b}}$ & $3.70 \pm 0.12^{\mathrm{b}}$ \\
\hline \multirow[t]{4}{*}{$\mathrm{pH}^{*}$} & 0 & $6.65 \pm 0.01^{\mathrm{c}}$ & $6.68 \pm 0.00^{c}$ & $6.59 \pm 0.02^{\mathrm{b}}$ & $6.62 \pm 0.00^{\mathrm{b}}$ & $6.63 \pm 0.00^{b}$ & $6.65 \pm 0.01^{b}$ \\
\hline & 1 & $6.72 \pm 0.00^{\mathrm{a}}$ & $6.70 \pm 0.00^{\mathrm{b}}$ & $6.54 \pm 0.00^{c}$ & $6.63 \pm 0.01^{\mathrm{b}}$ & $6.60 \pm 0.00^{c}$ & $6.66 \pm 0.00^{\mathrm{c}}$ \\
\hline & 2 & $6.70 \pm 0.01^{\mathrm{b}}$ & $6.77 \pm 0.00^{\mathrm{a}}$ & $6.58 \pm 0.00^{\mathrm{d}}$ & $6.66 \pm 0.00^{\mathrm{b}}$ & $6.58 \pm 0.00^{\mathrm{d}}$ & $6.67 \pm 0.00^{\mathrm{a}}$ \\
\hline & 3 & $6.69 \pm 0.00^{\mathrm{b}}$ & $6.68 \pm 0.00^{c}$ & $6.64 \pm 0.00^{\mathrm{a}}$ & $6.70 \pm 0.04^{\mathrm{a}}$ & $6.70 \pm 0.01^{\mathrm{a}}$ & $6.68 \pm 0.00^{\mathrm{a}}$ \\
\hline \multirow[t]{4}{*}{$\mathrm{TBA}^{*}$} & 0 & $0.027 \pm 0.012^{\mathrm{a}}$ & $0.028 \pm 0.019^{b}$ & $0.042 \pm 0.012^{\mathrm{a}}$ & $0.052 \pm 0.000^{\mathrm{b}}$ & $0.034 \pm 0.004^{b}$ & $0.027 \pm 0.004^{\mathrm{b}}$ \\
\hline & 1 & $0.027 \pm 0.004^{\mathrm{a}}$ & $0.034 \pm 0.004^{b}$ & $0.034 \pm 0.004^{\mathrm{ab}}$ & $0.030 \pm 0.000^{\mathrm{d}}$ & $0.040 \pm 0.004^{\mathrm{c}}$ & $0.015 \pm 0.000^{c}$ \\
\hline & 2 & $0.027 \pm 0.004^{\mathrm{a}}$ & $0.038 \pm 0.004^{\mathrm{ab}}$ & $0.038 \pm 0.004^{\mathrm{b}}$ & $0.061 \pm 0.004^{\mathrm{a}}$ & $0.037 \pm 0.004^{\mathrm{d}}$ & $0.021 \pm 0.004^{\mathrm{d}}$ \\
\hline & 3 & $0.026 \pm 0.004^{\mathrm{a}}$ & $0.036 \pm 0.004^{\mathrm{a}}$ & $0.036 \pm 0.004^{\mathrm{ab}}$ & $0.045 \pm 0.014^{\mathrm{c}}$ & $0.039 \pm 0.004^{\mathrm{a}}$ & $0.018 \pm 0.004^{\mathrm{a}}$ \\
\hline
\end{tabular}

"Means in a column having same superscript letters are not significantly different ( $>0.05)$. (mean $\pm \mathrm{SD}, \mathrm{n}=3$ )

CON: control soup, CF: calcium fortified soup, CP: Crude protein, TBA: Thiobarbutiric acid

Table 5. Changes in calcium and colour of processed shrimp soup during storage

\begin{tabular}{|c|c|c|c|c|c|c|c|}
\hline Parameters & Months & $121^{\circ} \mathrm{CON}$ & $121^{\circ} \mathrm{CF}$ & $115^{\circ} \mathrm{CON}$ & $115^{\circ} \mathrm{CF}$ & $110^{\circ} \mathrm{CON}$ & $110^{\circ} \mathrm{CF}$ \\
\hline \multirow[t]{4}{*}{ Calcium (ppm) } & 0 & $135.82 \pm 2.53^{\mathrm{a}}$ & $211.06 \pm 2.49^{\mathrm{ab}}$ & $147.88 \pm 2.27^{\mathrm{a}}$ & $213.00 \pm 2.13^{\mathrm{a}}$ & $111.68 \pm 1.30^{\mathrm{a}}$ & $193.99 \pm 1.44^{\mathrm{a}}$ \\
\hline & 1 & $133.66 \pm 1.73^{\mathrm{ab}}$ & $211.97 \pm 2.04^{\mathrm{ab}}$ & $148.86 \pm 0.44^{\mathrm{a}}$ & $213.15 \pm 1.32^{\mathrm{a}}$ & $112.06 \pm 1.00^{\mathrm{a}}$ & $194.84 \pm 4.73^{\mathrm{a}}$ \\
\hline & 2 & $133.02 \pm 1.12^{\mathrm{ab}}$ & $211.17 \pm 1.48^{\mathrm{a}}$ & $148.35 \pm 1.41^{\mathrm{a}}$ & $213.16 \pm 1.20^{\mathrm{a}}$ & $112.37 \pm 1.28^{\mathrm{a}}$ & $197.07 \pm 3.24^{\mathrm{a}}$ \\
\hline & 3 & $131.47 \pm 1.11^{\mathrm{b}}$ & $208.52 \pm 2.94^{\mathrm{b}}$ & $143.57 \pm 1.19^{b}$ & $212.69 \pm 1.89^{\mathrm{a}}$ & $109.60 \pm 2.74^{\mathrm{a}}$ & $195.79 \pm 4.21^{\mathrm{a}}$ \\
\hline \multirow[t]{4}{*}{$\mathrm{L}^{*}$} & 0 & $69.50 \pm 0.03^{\mathrm{d}}$ & $68.50 \pm 0.03^{\mathrm{ab}}$ & $68.00 \pm 0.02^{\mathrm{b}}$ & $67.49 \pm 0.03^{c}$ & $66.80 \pm 0.06^{\mathrm{c}}$ & $66.21 \pm 0.03^{\mathrm{a}}$ \\
\hline & 1 & $68.96 \pm 0.11^{\mathrm{c}}$ & $69.73 \pm 0.08^{\mathrm{ab}}$ & $68.76 \pm 0.34^{b}$ & $68.13 \pm 0.09^{b}$ & $66.40 \pm 0.02^{\mathrm{b}}$ & $66.16 \pm 0.04^{\mathrm{a}}$ \\
\hline & 2 & $69.43 \pm 0.39^{b}$ & $69.27 \pm 0.12^{\mathrm{a}}$ & $68.91 \pm 0.26^{b}$ & $67.03 \pm 0.11^{\mathrm{d}}$ & $66.21 \pm 1.14^{\mathrm{d}}$ & $66.11 \pm 0.45^{\mathrm{b}}$ \\
\hline & 3 & $68.65 \pm 0.23^{\mathrm{a}}$ & $68.89 \pm 0.46^{\mathrm{b}}$ & $70.04 \pm 0.52^{\mathrm{a}}$ & $68.18 \pm 0.04^{\mathrm{a}}$ & $66.03 \pm 0.05^{\mathrm{a}}$ & $66.13 \pm 0.12^{\mathrm{c}}$ \\
\hline \multirow[t]{4}{*}{$a^{*}$} & 0 & $-1.53 \pm 0.03^{-b}$ & $-1.66 \pm 0.02^{-\mathrm{a}}$ & $-2.14 \pm 0.03^{-a}$ & $-1.76 \pm 0.04^{-\mathrm{a}}$ & $-1.45 \pm 0.04^{-\mathrm{c}}$ & $-2.03 \pm 0.04^{-\mathrm{c}}$ \\
\hline & 1 & $-1.56 \pm 0.25^{-\mathrm{c}}$ & $-1.79 \pm 0.09^{-\mathrm{a}}$ & $-1.97 \pm 0.21^{-\mathrm{b}}$ & $-1.78 \pm 0.06^{-\mathrm{a}}$ & $-1.66 \pm 0.10^{-\mathrm{b}}$ & $-1.55 \pm 0.08^{-\mathrm{bc}}$ \\
\hline & 2 & $-2.14 \pm 0.05^{-\mathrm{c}}$ & $-2.00 \pm 0.07^{-\mathrm{a}}$ & $-1.65 \pm 0.05^{-\mathrm{a}}$ & $-2.20 \pm 0.04^{-b}$ & $-1.30 \pm 0.11^{-\mathrm{a}}$ & $-1.85 \pm 0.06^{-\mathrm{b}}$ \\
\hline & 3 & $-2.11 \pm 0.47^{-\mathrm{c}}$ & $-1.82 \pm 0.09^{-\mathrm{a}}$ & $-2.01 \pm 0.06^{-\mathrm{b}}$ & $-1.92 \pm 0.07^{\text {-a }}$ & $-2.01 \pm 0.04^{-\mathrm{c}}$ & $-1.39 \pm 0.12^{-\mathrm{a}}$ \\
\hline \multirow[t]{4}{*}{$b^{*}$} & 0 & $4.47 \pm 0.02^{\mathrm{a}}$ & $4.35 \pm 0.02^{\mathrm{b}}$ & $4.63 \pm 0.02^{\mathrm{a}}$ & $5.23 \pm 0.02^{\mathrm{c}}$ & $4.11 \pm 0.03^{c}$ & $5.03 \pm 0.02^{\mathrm{c}}$ \\
\hline & 1 & $4.45 \pm 0.22^{\mathrm{c}}$ & $5.55 \pm 0.22^{\mathrm{ab}}$ & $4.15 \pm 0.27^{\mathrm{a}}$ & $5.76 \pm 0.10^{\mathrm{a}}$ & $4.63 \pm 0.03^{\mathrm{bc}}$ & $5.57 \pm 0.05^{\mathrm{bc}}$ \\
\hline & 2 & $4.47 \pm 0.30^{\mathrm{c}}$ & $5.57 \pm 0.07^{\mathrm{ab}}$ & $4.89 \pm 0.24^{\mathrm{a}}$ & $5.83 \pm 0.15^{\mathrm{b}}$ & $4.48 \pm 0.20^{\mathrm{b}}$ & $6.01 \pm 0.24^{b}$ \\
\hline & 3 & $4.18 \pm 1.46^{\mathrm{b}}$ & $6.13 \pm 0.09^{\mathrm{a}}$ & $4.29 \pm 0.09^{\mathrm{a}}$ & $5.90 \pm 0.14^{\mathrm{a}}$ & $4.93 \pm 0.10^{\mathrm{a}}$ & $5.81 \pm 0.14^{\mathrm{a}}$ \\
\hline
\end{tabular}

The parameters determined are of colour as of CIEL $\left(\mathrm{L}^{*}=0\left[\right.\right.$ black] and $\mathrm{L}^{*}=100$ [white]), CIEa* $\left(-\mathrm{a}=\right.$ greenness and $+\mathrm{a}^{*}=$ redness $)$, and CIEb $\left(-\mathrm{b}^{*}=\right.$ blueness $^{*}$ and $+\mathrm{b}^{*}=$ yellowness). $\mathrm{CON}$ : control soup, $\mathrm{CF}$ : calcium fortified soup.

Means in a column with the same superscript letters are not significantly different $(\mathrm{p}>0.05)$. (mean \pm SD, $n=3)$

fortified and control soup during storage were found to be nil. This could be due to the fact that oxidation of the fat might have been over during frying of shrimp and there was no scope for free radical formation during storage. Similar observations were reported by Srivatsa et al. (1993) while studying canned fish curry and by Mohan (2004) in prawn kuruma.

The calcium content of fish bone powder was $20.24 \%$. Calcium content of the control and fortified raw soup were 149.2 and $213.1 \mathrm{ppm}$ respectively. FDA has established a Daily Value (DV) of calcium at 1,000 mg day ${ }^{-1}$ for adults and children older than age 4. No significant difference $(p<0.05)$ in calcium content was observed in samples after thermal processing and there was no adverse effect on other constituents in the soup as per organoleptic evaluation. Similar result was also reported by Haro et al. (2006) in calcium fortified juice. Steven et al. (2001) reported that addition of moderate amount of calcium to a cereal product was beneficial to calcium absorption and did not interfere with iron absorption. Changes of lightness, redness and yellowness of shrimp soup after thermal processing are presented in Table 5. It was observed that as the processing time increased, more browning products were produced which is reflected by the decreased $\mathrm{L}^{*}$ value and the increased $b^{*}$ value and slight increase in redness. The $\mathrm{L}^{*}$ and $\mathrm{b}^{*}$ values were significantly $(\mathrm{p}<0.05)$ affected 
by the processing time. However the values did not show significant changes during storage. The change in colour during thermal processing was explained by Whistler and Daniel (1985). More browning products were formed with increase in temperature and time of processing. According to Haard (1992), shorter process time results in lighter products. Moreover, protein-lipid reactions may contribute to the colour change that involves the oxidation of the fatty acids and the reaction of decomposition products with proteins (Haard, 1992). The $\mathrm{L}^{*}$ value of shrimp soup was not influenced by calcium fortification, whereas $b^{*}$ value was increased after fortification. A similar result was reported by Chio (2002) in chicken nuggets. A decrease in viscosity was observed in calcium fortified soup irrespective of processing temperature (Fig. 2), which may be due to the gelatinisation of starch present in corn flour during the fortification process which led to the breakage of large proportion of the starch granules. This in turn lowered the ability of the granules to swell. Moreover, interaction between starch molecule and $\mathrm{Ca}^{2+}$ could decrease starch solubility (Bryant and Hamaker, 1997; Ch et al., 2014). Similar results were also reported by Martin et al. (2006) and by Karl et al. (1983) in thermally processed soy beverages.

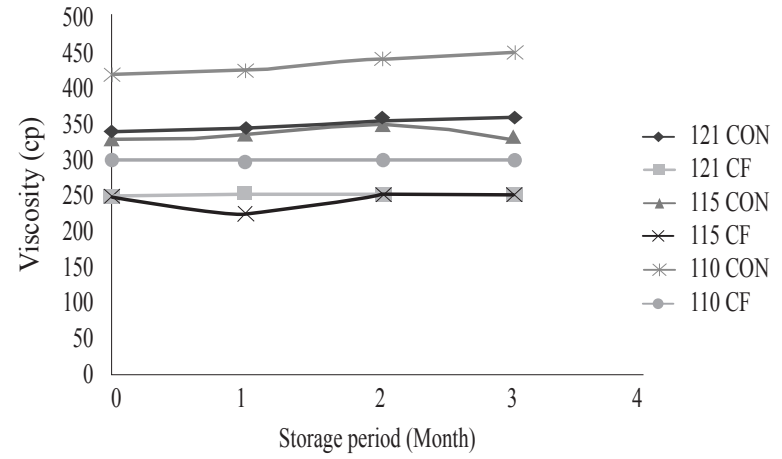

Fig. 2. Changes in viscosity of calcium fortified and control soups CON: Control soup, CF: Calcium fortified soup. Each value is average of at least 3 replications

Sensory evaluations of soups in retortable pouches were carried out at every 30 days interval for three months using a 9 point hedonic scale. The results are presented in Table 6. It was observed that there was a slight decrease in sensory parameters upon storage. Viscosity was rated high for control soup than for the fortified soups. This might be due to the incorporation of fortifying agent but the variation was not significanly high. The viscosity was low for 110 than that for $121^{\circ} \mathrm{C}$; this might be because

Table 6. Changes in sensory scores* during storage of calcium fortified and control soup

\begin{tabular}{|c|c|c|c|c|c|c|c|c|}
\hline $\begin{array}{l}\text { Storage period } \\
\text { (Months) }\end{array}$ & Treatments & Appearance & Colour & Odour & Flavour & Taste & Consistency & $\begin{array}{l}\text { Overall } \\
\text { acceptability }\end{array}$ \\
\hline \multirow{6}{*}{ Zero month } & $1 \mathrm{CF}$ & $8.3 \pm 0.01$ & $8.2 \pm 0.1$ & $8.4 \pm 0.05$ & $8.2 \pm 0.06$ & $8.3 \pm 0.06$ & $8.3 \pm 0.04$ & $8.2 \pm 0.04$ \\
\hline & $2 \mathrm{CF}$ & $8.4 \pm 0.06$ & $8.3 \pm 0.09$ & $8.4 \pm 0.07$ & $8.5 \pm 0.04$ & $8.5 \pm 0.03$ & $8.3 \pm 0.01$ & $8.1 \pm 0.03$ \\
\hline & $3 \mathrm{CF}$ & $8.2 \pm 0.07$ & $8.1 \pm 0.04$ & $8.3 \pm 0.04$ & $8.2 \pm 0.2$ & $8.2 \pm 0.04$ & $7.9 \pm 0.01$ & $8.0 \pm 0.06$ \\
\hline & $1 \mathrm{CON}$ & $8.3 \pm 0.07$ & $8.2 \pm 0.03$ & $8.4 \pm 0.04$ & $8.2 \pm 0.07$ & $8.3 \pm 0.09$ & $8.7 \pm 0.1$ & $8.2 \pm 0.02$ \\
\hline & $2 \mathrm{CON}$ & $8.4 \pm 0.04$ & $8.3 \pm 0.3$ & $8.4 \pm 0.04$ & $8.4 \pm 0.04$ & $8.3 \pm 0.01$ & $8.5 \pm 0.2$ & $8.1 \pm 0.05$ \\
\hline & $3 \mathrm{CON}$ & $8.3 \pm 0.07$ & $8.1 \pm 0.09$ & $8.3 \pm 0.08$ & $8.3 \pm 0.02$ & $8.2 \pm 0.04$ & $8.3 \pm 0.07$ & $8.0 \pm 0.06$ \\
\hline \multirow{6}{*}{ First month } & $1 \mathrm{CF}$ & $8.1 \pm 0.04$ & $8.1 \pm 0.07$ & $8.2 \pm 0.06$ & $8.0 \pm 0.01$ & $8.2 \pm 0.05$ & $8.2 \pm 0.07$ & $8.0 \pm 0.1$ \\
\hline & $2 \mathrm{CF}$ & $8.2 \pm 0.04$ & $8.2 \pm 0.01$ & $8.2 \pm 0.04$ & $8.3 \pm 0.09$ & $8.3 \pm 0.05$ & $8.2 \pm 0.06$ & $8.0 \pm 0.09$ \\
\hline & $3 \mathrm{CF}$ & $8.0 \pm 0.01$ & $8 \pm 0.01$ & $8.2 \pm 0.04$ & $8.1 \pm 0.05$ & $8.2 \pm 0.05$ & $8.0 \pm 0.06$ & $7.8 \pm 0.08$ \\
\hline & $1 \mathrm{CON}$ & $8.1 \pm 0.04$ & $8.1 \pm 0.05$ & $8.3 \pm 0.03$ & $8.1 \pm 0.07$ & $8.2 \pm 0.09$ & $8.3 \pm 0.08$ & $8.0 \pm 0.2$ \\
\hline & $2 \mathrm{CON}$ & $8.2 \pm 0.01$ & $8.1 \pm 0.03$ & $8.2 \pm 0.05$ & $8.2 \pm 0.04$ & $8.1 \pm 0.06$ & $8.2 \pm 0.05$ & $7.9 \pm 0.4$ \\
\hline & $3 \mathrm{CON}$ & $8.1 \pm 0.04$ & $8.0 \pm 0.04$ & $8.1 \pm 0.6$ & $8.2 \pm 0.4$ & $8.2 \pm 0.1$ & $8.0 \pm 0.07$ & $7.8 \pm 0.05$ \\
\hline \multirow{6}{*}{ Second month } & $1 \mathrm{CF}$ & $7.6 \pm 0.1$ & $7.8 \pm 0.1$ & $7.8 \pm 0.6$ & $7.9 \pm 0.09$ & $7.8 \pm 0.4$ & $7.8 \pm 0.1$ & $7.8 \pm 0.3$ \\
\hline & $2 \mathrm{CF}$ & $7.5 \pm 0.3$ & $7.8 \pm 0.5$ & $7.7 \pm 0.6$ & $7.8 \pm 0.4$ & $7.7 \pm 0.1$ & $7.6 \pm 0.3$ & $7.6 \pm 0.4$ \\
\hline & $3 \mathrm{CF}$ & $7.4 \pm 0.7$ & $7.7 \pm 0.2$ & $7.7 \pm 0.1$ & $7.8 \pm 0.1$ & $7.7 \pm 0.2$ & $7.6 \pm 0.3$ & $7.5 \pm 0.7$ \\
\hline & $1 \mathrm{CON}$ & $7.5 \pm 0.3$ & $7.9 \pm 0.6$ & $7.9 \pm 0.4$ & $7.7 \pm 0.6$ & $7.8 \pm 0.1$ & $7.8 \pm 0.6$ & $7.8 \pm 0.3$ \\
\hline & $2 \mathrm{CON}$ & $7.5 \pm 0.1$ & $7.9 \pm 0.9$ & $7.8 \pm 0.6$ & $7.7 \pm 0.3$ & $7.6 \pm 0.4$ & $7.6 \pm 0.6$ & $7.6 \pm 0.4$ \\
\hline & $3 \mathrm{CON}$ & $7.4 \pm 0.4$ & $7.8 \pm 0.3$ & $7.8 \pm 0.1$ & $7.6 \pm 0.1$ & $7.6 \pm 0.4$ & $7.6 \pm 0.1$ & $7.5 \pm 0.3$ \\
\hline \multirow{6}{*}{ Third month } & $1 \mathrm{CF}$ & $7.5 \pm 0.4$ & $7.5 \pm 0.6$ & $7.7 \pm 0.1$ & $7.8 \pm 0.4$ & $7.6 \pm 0.1$ & $7.6 \pm 0.4$ & $7.6 \pm 0.5$ \\
\hline & $2 \mathrm{CF}$ & $7.3 \pm 0.4$ & $7.4 \pm 0.3$ & $7.6 \pm 0.4$ & $7.8 \pm 0.4$ & $7.5 \pm 0.3$ & $7.4 \pm 0.4$ & $7.5 \pm 0.4$ \\
\hline & $3 \mathrm{CF}$ & $7.3 \pm 0.4$ & $7.3 \pm 0.7$ & $7.7 \pm 0.6$ & $7.7 \pm 0.4$ & $7.4 \pm 0.6$ & $7.4 \pm 0.7$ & $7.4 \pm 0.4$ \\
\hline & $1 \mathrm{CON}$ & $7.4 \pm 0.4$ & $7.6 \pm 0.6$ & $7.7 \pm 0.4$ & $7.7 \pm 0.9$ & $7.6 \pm 0.3$ & $7.7 \pm 0.9$ & $7.6 \pm 0.2$ \\
\hline & $2 \mathrm{CON}$ & $7.3 \pm 0.7$ & $7.6 \pm 0.7$ & $7.7 \pm 0.5$ & $7.5 \pm 0.4$ & $7.5 \pm 0.4$ & $7.6 \pm 0.09$ & $7.4 \pm 0.9$ \\
\hline & $3 \mathrm{CON}$ & $7.2 \pm 0.4$ & $7.5 \pm 0.1$ & $7.6 \pm 0.3$ & $7.3 \pm 0.3$ & $7.3 \pm 0.4$ & $7.6 \pm 0.3$ & $7.4 \pm 0.1$ \\
\hline
\end{tabular}

CF: Calcium fortified soup, CON: Control soup, $1 \mathrm{CF}, 2 \mathrm{CF}, 3 \mathrm{CF}$ and $1 \mathrm{C}, 2 \mathrm{C}, 3 \mathrm{C}$ : samples of $121^{\circ} \mathrm{C}, 115^{\circ} \mathrm{C}$ and $110^{\circ} \mathrm{C}$ respectively

"Each value is mean \pm SD of atleast 10 replications 
of longer heating time given for the soup processed at $110^{\circ} \mathrm{C}$. As there was not much variation in control and fortified soups, it can be inferred that fortification did not have any negative impact on sensory characteristics. It was also observed that calcium fortified soup had better scores for taste than control soup. The overall sensory scores were higher for soup processed at $121^{\circ} \mathrm{C}$, than other temperatures for both fortified and control soup. This might be due to minimum exposure time of heat treatment at $121^{\circ} \mathrm{C}$, compared to other temperatures. During storage, though the sensory scores decreased but were not significant and the soup was in acceptable condition even after 3 months of storage at ambient temperature of $28 \pm 2^{\circ} \mathrm{C}$.

Analysis of various physico-chemical and sensory parameters indicated that shrimp soup processed at $121^{\circ} \mathrm{C}$ at $F_{0}$ value of 6.0 had better acceptability. Addition of calcium had no adverse effects on appearance and on any other quality attributes. Calcium fortified soup in ready to drink form could be used as a tool to combat calcium deficiency.

\section{Acknowledgements}

Authors thank the Director, ICAR-Central Institute of Fisheries Technology, Kochi, for providing facilities to carry out this work.

\section{References}

AOAC 2000. Official methods of analysis. Association of Official Analytical Chemists, Maryland, USA.

Aubourg, S., Medina, I. and Perez-Martin, R. 1995. A comparison between conventional and fluorescence detection methods of cooking-induced damage to tuna fish lipids. Zeitschrift fur Lebensmittel Untersuchungund-Forschung., 200: 252-255.

Bell, J. W., Farkas, B. E., Hale, S. A. and Lanier, T. C. 2001. Effect of thermal treatment on moisture transport during steam cooking of skipjack tuna (Katsuwonas pelamis). J. Food Sci., 66(2): 307-313.

Bindu, J., Gopal, T. K. S. and Unnikrishnan Nair, T. S. 2004. Ready-toeat mussel meat processed in retortable pouches for the retail and export market. Packag. Technol Sci., 17: 113-117.

Broadus, A. E. 1996. Mineral balance and homeostasis. In: Favus, M. J. (Eds.), Primer on the metabolic bone diseases and disorders of mineral metabolism, $3^{\text {rd }}$ edn., Lippincott Raven, Philadelphia, p. 57-63.

Bryant, C. M. and Hamaker, B. R. 1997. Effect of lime on gelatinisation of corn flour and starch. Cereal Chem., 74: 171-175.

Castrillon, A., Navarro, P. and Garcia-Arias, M. 1996. Tuna protein nutritional quality changes after canning. J. Food Sci., 61: $1250-1253$

Ch, W., Anwar, C., Astuti, M. and Supriyadi 2014. Pasting properties of calcium fortified rice. Int. J. Food Res., 21(3): 1025-1029.
Cheuk, W. L. and Finne, G. 1981. Decomposition (chemical indices), modified colorimetric method for determining Indole in shrimp. Association of Official Analytical Chemists, 64(4): 783-785.

Chia, S. S., Baker, R. C. and Hotchkiss, J. H. 1983. Quality comparison of thermo processed fishery products in cans and retortable pouches. J. Food Sci., 48: 1521-1531.

Chio, Y. I. 2002. Effect of calcium and iron on quality and shelf-life of chicken nuggets. Annual Meeting and Food Expo - Anaheim, California, p. 06-18.

Conway, E. J. 1950. Micro diffusion analysis of volumetric error. Crosby, Lockwood and Son Ltd., London.

FAO/WHO 1994. Codex Alimentarius, vol. 4, $2^{\text {nd }}$ edn.

Goldfarb, P. L. 1970. Pouch for low acid foods. Mod. Packag., 43(12): 70-72.

Haard, N. F. 1992. Biochemistry and chemistry of color and color changes in seafoods. In: Flick, G. J. and Martin, R. E, (Eds.), Advances in seafood biochemistry: composition and quality, Technomic Publishing Company Inc., Lancaster Pa, p. 305-360.

Haro, J. F., Martinez, C., Ros, G. and Vidal, M. L. 2006. Stability of calcium bioaccessibility and sensory parameters during the storage of fortified juices. Food Sci. Tech. Int., 12(4): 281-285.

Heidelbaugh, N. D. and Karel, M. 1970. Changes in pouched heatprocessed foods. Modern Packag., 43(11): 80-90.

Holt, S. H. A. and Miller, J. B. 1995. Increased insulin responses to ingested foods are associated with lessened satiety. Appetite, 24: 43-54.

Hu, K. H., Nelson, A., Legault, R. R. and Steinberg M. P. 1995 Feasibility of using plastic film packages for heat processed foods. Food Technol., 19(9): 236-240.

Huss, H. H. 1995. Quality and quality changes in fresh fish. Fisheries Technical Paper No 348. Food and Agricultural Organisation of the United Nations, Rome, Italy, p. 195-202.

IS: 2168-1971. Specification for pomfret canned in oil. Indian Standard Institute, New Delhi, India.

Karel, M., Fennema, O. R. and Lund, D. B. 1975. Principles of food science. Part II. Marcel Dekker, New York, USA.

Karl, W. E., Alvin Nelson, I. and John Erdman, W. 1983. Effects of calcium addition on stability and sensory properties of soy beverage. J. Food Sci., 48(1): 256-257.

Kaushik, R., Sachdeva, B., Arora, S. and Wadhwa, B. K. 2014. Development of an analytical protocol for the estimation of vitamin D2 in fortified toned milk. Food Chem., 151: 225-230.

Kaushik, R., Sachdeva, B. and Arora, S. 2015. Heat stability and thermal properties of calcium fortified milk. J. Food. Sci., 13(2): 305-311.

Kong, F., Tang, J., Rasco, B. and Crapo, C. 2007. Kinetics of salmon quality changes during thermal processing. J. Food Eng., 83: $510-520$.

Mallick, A. K. 2003. Suitability of polymer coated tin free steel cans for canning rohu (Labeo rohita) in curry medium. M.F. Sc. thesis submitted to the ICAR-Central Institute of Fisheries Education, Mumbai. 
Martin Jefferies, Geoffrey Pass, Glyn, O. P. and Mat, B. Z. 2006. The effect of metal ion content on the viscosity of gum ghatti. J. Sci Food Agr., 29(2): 193-200.

Meilgaard, M. C., Civille, G. V. and Carr, B. T. 1999. Sensory evaluation techniques, $3^{\text {rd }}$ edn., CRC Press Ltd., Boca Raton, Florida, $416 \mathrm{pp}$.

Mohan, C. O. 2004. Thermal processing of prawn kuruma (Penaeus indicus) in retortable pouch and aluminium can. M.F.Sc. thesis submitted to the ICAR-Central Institute of Fisheries Education, Mumbai.

Mohan, C. O., Ravishankar, C. N., Bindu, J., Geetalakshmi, V. and Srinivasa Gopal, T. K. 2006. Effect of thermal process time on quality of "shrimp kuruma" in retortable pouches and aluminum cans. J. Food Sci., 71(6): S496-

NCA 1968. Laboratory manual for food canners and processors, vol. 1, S500, National Canners Association, Westport, New York, NY, $236 \mathrm{pp}$.

Pokorny, J. 1981. Browning for lipid-protein interactions. Prog. Food Nutr. Sci., 5: 421-428.

Prasanna, S. 2004. Effect of high temperature processing on process time and on the quality of oilsardine (Sardinella longiceps). M. F. Sc thesis submitted to the ICAR-Central Institute of Fisheries Education, Mumbai.
Ranganna, S. 2000. Handbook of canning and aseptic packaging. Tata Mc Graw Hill Publishing Co. Ltd, New Delhi, India, p. 507-508.

Ravishankar, C. N., Gopal, T. K. S. and Vijayan, P. K. 2002. Studies on heat processing and storage of seer fish curry in retort pouches. Packaging Tech. Sci., 15: 3-7.

Srivatsa, A. N., Ramakrishna, A., Gopinathan, V. K., Nataraju, S., Leela, R. K., Jayaraman, K. S. and Sankaran, R. 1993. Suitability of indigenously fabricated aluminium cans for canning of Indian foods. J. Food Sci. Technol., 30(6): 429-434.

Steven, A., Abrams, M. D., Ian J., Griffin, M. B., ChB Penni Davila, B. S. and Lily Liang, M. A. 2001. Calcium fortification of breakfast cereal enhances calcium absorption in children without affecting iron absorption. J. Pediatr., 139: 522-6.

Stumbo, C. R. 1973. Thermobacteriology in food processing, $2^{\text {nd }} e d n$., Academic Press, Inc., New York, 329 pp.

Tarladgis, G. B., Watts, M. B. and Younathan, T. M. 1960. A distillation method for the quantitative determination of malonaldehyde in rancid foods. J. Am. Oil Chem. Soc., 37: 44-50.

Whistler, R. L. and Daniel, J. R. 1985. Carbohydrates. In: O. R. Fennema (Eds.), Food Chem., Marcel Dekker, p. 98-99.

http://www.fda.gov/ForConsumers/ConsumerUpdates/ucm050803.htm (Accessed 12 ${ }^{\text {th }}$ November 2015). 